\title{
Stress before and during pregnancy increased risk antepartum depression
}

\author{
R. Irawati Ismail
}

\begin{abstract}
Abstrak
Makalah ini menyajikan risiko depresi antepartum (DAP) di antara wanita hamil, khususnya faktor stress sebelum hamil, stress selama hamil, kesesuaian perkawinan, dukungan sosial, status mental suami dan pengeluaran per-bulan. Subjek terdiri dari 580 wanita hamil triwulan ketiga yang melakukan pemeriksaan antenatal di Bagian Kebidanan Rumah Sakit Persahabatan (RSP) Jakarta. Sampel diambil sejak 1 Nopember 1999 - 15 Agustus 2002. Depresi antepartum ditapis dengan Edinburgh postnatal depression scale (EPDS), titik potong (cut-off score) $\geq 13$, penilaiannya dilakukan oleh psikiater. Informasi yang diperoleh melalui wawancara adalah data demografi dan karakteristik individu, hasil lembar pertanyaan terstruktur untuk data stres sebelum dan selama hamil, sedangkan kuesioner KDS, KHSI dan SCL-90 berturut-turut untuk mengukur dukungan sosial, kesesuaian hubungan perkawinan dan status mental suami (SCL-90). Prevalensi DAP di antara wanita hamil sebesar 18\%. Depresi antepartum tidak terbukti berkaitan dengan faktor umur, tingkat pendidikan, pekerjaan, pengeluaran per-bulan, jumlah kehamilan, jumlah anak, jumlah persalinan, kesehatan fisik ibu, dan riwayat sindroma premenstruasi. Wanita hamil yang mengalami stres sebelum hamil berisiko dua kali lipat mengalami DAP [odds ratio $(O R)$ suaian $=2,04 ; 95 \%$ interval kepercayaan $(I K): 1,12-3,74$ ] dibandingkan dengan yang tidak mengalami stres sebelum hamil. Demikian pula wanita hamil yang mengalami stres saat hamil dibandingkan yang tidak mengalami stres saat hamil berisiko 2,2 kali lipat mengalami DAP (OR suaian = 2,13, 95\% IK: 1,27-3,74). Dapat disimpulkan stres sebelum dan selama hamil meningkatkan risiko depresi antepartum. Oleh karena itu faktor risiko tersebut harus mendapat perhatian bagi yang menangani ibu hamil. (Med J Indones 2003; 12: 81-6)
\end{abstract}

\begin{abstract}
This paper presents the risk of antepartum depression (APD) among pregnant women. In particular stress before pregnancy, stress during pregnancy, marital relationship, social support, husband's mental status and monthly expenditure. The subjects consisted of 580 pregnant women in the third trimester, who attended antenatal care at the Department of Obstetrics of the Persahabatan Hospital Jakarta from November 1, 1999 to August 15, 2001. Antepartum depression was screened by a psychiatrist using the Edinburgh Postnatal Depression Scale (EPDS). Information on demographic and personal characteristics were collected from fill-in form. Through this form, the respondent gave information on stress before and during pregnancy, and from questionnaires Kuestioner Dukungan Sosial (KDS), Kesesuaian Hubungan Suami Istri (KHSI) and the Symptom Check List-90 (SCL-90) information about social support, marital relationship, and husband's mental status were collected respectively. The prevalence of APD was $18 \%$. Antepartum depression and non-antepartum depression were similar in terms of age groups, level of education, occupations, monthly expenditures, number of pregnancies, number of children, number of deliveries, physical health condition, and history of premenstrual syndromes. Pregnant women with stress before pregnancy had a two-fold risk of APD [adjusted odds ratio (OR) $=2.04 ; 95 \%$ confidence intervals (CI): 1.12 - 3.74] compared to pregnant women without stress before pregnancy. In addition, when compared to pregnant women without stress during pregnancy, those with stress during pregnancy had 2.2-fold risk of developing APD (adjusted OR=2.13, 95\% CI: 1,27-3,74). In conclusion, stress before and during pregnancy increased the risk antepartum depression. Therefore, attention should be paid to pregnant women with these risk factors. (Med J Indones 2003; 12: 81-6)
\end{abstract}

Keywords: antepartum depression, stress before pregnancy, stress during pregnancy

Even though antepartum depression (APD) usually disappears when the baby is delivered, it might have some adverse impact, such as no weight gain during

Department of Psychiatry, Faculty of Medicine, University of Indonesia/Dr. Cipto Mangunkusumo Hospital, Jakarta, Indonesia. pregnancy, resulting in premature births or babies with low birth weights. ${ }^{1}$ More over, APD could continue into the postnatal period, ${ }^{1}$ and might lead to potentially serious effects ${ }^{2}$ such as suicide. ${ }^{3}$ The disorder is characterized by feelings of sadness or anxiety, loss of appetite, fatigue, and sleep disorders, either too little or too much sleep. ${ }^{4}$ 
Previous studies revealed that APD was related to several risk factors, such as financial and housing problems, negative life events, and inadequate social support. These risk factors were all linked to high depressive symptomatology during pregnancy. ${ }^{4}$ Other factors linked to APD were, marital conflicts, neurotic pre-morbidity, and other psychiatric problems. ${ }^{5}$ These factors reflect APD as multi-factorial.

No comprehensive study identifying the risk factors related to APD has ever been conducted in Indonesia. Therefore, it would be beneficial to study and investigate several risk factors related to APD such as stress before and during pregnancy, marital harmony, social support, mental health status of husband, and monthly expenditure.

\section{METHODS}

The subjects were pregnant women who attended antenatal care at the Department of Obstetrics of the Persahabatan Hospital (RSP) Jakarta from 1 November 1999 to 15 August 2001. Consecutive sampling was used.

The pregnant women included in this study were those in the third trimester of pregnancy, able to read and write Indonesia language, married, and have signed an informed consent form. Those who had a history of psychiatric disorder, either schizophrenia or other psychotic disorders were excluded from this study.

The information collected pertained to demographic, obstetrical, and gynecological characteristics, as well as mental health conditions. The author collected information in the hospital consultation room, interviewed respondents, and filled-in demographic and personal characteristics forms. Information on stress before and during pregnancy was filled in by the respondent themselves. Information regarding social support and marital relationship were reported by the respondent through Kuestioner Dukungan Sosial (KDS) and KHSI questionnaires. The husbands were also interviewed using the Kesesuaian Hubungan Suami Istri (KHSI) questionnaires. The Symptom Check List90 (SCL-90) was also administered to the husbands to find out the their mental status. Antepartum depression was screened using the Edinburgh Postnatal Depression Scale (EPDS) by the psychiatrist. Subjects were diagnosed as APD if they had an EPDS score of 13 or more. ${ }^{6}$ Those who had an EPDS score of less than 13 were categorized as non APD subjects.
Stress before pregnancy was defined as a significant unpleasant condition before pregnancy, whereas stress during pregnancy is a significant unpleasant condition during pregnancy. The symptoms check list 90 (SCL90) was used to gauge the husband's mental health. The cut-off score for indicating psychopathology was $61 .^{7}$ Any history of depressive episode, with or without therapy, was included.

The extent of social support was elicited by scoring using a standard social support questionnaire $K D S$. A score of 13 or more means no social support is present; while a score of less than 13 means social support is present. Harmony in marital relationship was measured and scored using the KHSI questionnaire. A score of 16 or more means marital adjusted is not present; and score of less than 16 means marital adjusted is present.

For this study, premenstrual syndrome history consisted of mild menstrual problems with symptoms of irritability, tension, dysphoria, or mood lability, with or without somatic symptoms. The symptoms, single or combined, should appear before menstruation and disappear early in menstruation.

A number of risk factors were examined as potential confounders and/or effect modifiers, including: age (16-20, 21-40, and 41-44 years); education (low = none-junior high school, middle $=$ senior high school, and high = university graduates); occupation (employed, unemployed included housewives); monthly expenditures $($ low $=$ Rp $19.000-$ Rp 79.799; middle $=$ Rp.80.000 - Rp 149.999; high = Rp.150.000 - Rp 950.000); number of pregnancies (first pregnancy, 2-15 ${ }^{\text {th }}$ pregnancies); number of children (none, one child, and 2-9 children).

Logistic regression analysis ${ }^{8}$ was used in order to control for the confounding effects of risk factors on the relationship between the risk factors and APD. A risk factor was considered to be a potential confounder if upon completing of the univariate test, the $\mathrm{p}$-value $<0.25$ and will be considered as a candidate for the multivariate model along with all risk factors of known biological importance.

Characteristics that fulfilled this definition as confounders are included by the method of maximum likelihood. Ninety-five percent confidence intervals were based on the standard error of coefficient estimates. Calculation used unconditional logistic methods, and based on candidates of potential to be 
risk factors. For the simplicity, the final model was constructed by stepwise method using STATA version 6 software. ${ }^{10}$

The research proposal was approved by the Ethical Committee of Faculty of Medicine, University of Indonesia, Jakarta.

\section{RESULTS}

The number of subjects that agreed to participate in the study was 681. However, 101 women were excluded because they did not return the completed data, such as the KDS, KHSI, SCL-90, information on stresses before or during pregnancy. This left 580 women as subjects for this analysis.
Out of 580 pregnant women who had antenatal care, $104(18 \%)$ suffered from APD. They were screen by EPDS with scores ranging from 0-23 (mean 9.06, standard of deviation 4.29).

Table 1 and Table 2 were univariate analysis results. Table 1 showed that APD and non-APD subjects were similarly distributed with respect to age group, occupation, number of pregnancies, number of children, number of deliveries and physical health of the mothers. APD subjects were more likely to have low education level compared to non-APD.

Table 2, showed that marital adjustment of wife, history of depressive episode increased the risk of APD. Furthermore, the presence of a history of premenstrual syndrome moderate increased the risk of APD.

Table 1. Some demographic characteristics of subjects and risk of antepartum depression (APD)

\begin{tabular}{|c|c|c|c|c|c|c|}
\hline & \multicolumn{2}{|c|}{$\begin{array}{c}\text { Non-APD } \\
(\mathrm{N}=476)\end{array}$} & \multicolumn{2}{|c|}{$\begin{array}{c}\text { APD } \\
(\mathrm{N}=104)\end{array}$} & \multirow[t]{2}{*}{$\begin{array}{l}\text { Crude odds } \\
\text { ratio }\end{array}$} & \multirow[t]{2}{*}{$\begin{array}{c}95 \% \\
\text { confidence intervals }\end{array}$} \\
\hline & $\mathrm{n}$ & $\%$ & $\mathrm{n}$ & $\%$ & & \\
\hline \multicolumn{7}{|l|}{ Age (years) } \\
\hline $21-40$ & 450 & 94.5 & 96 & 92.3 & 1.00 & Reference \\
\hline $16-21$ & 19 & 4.0 & 6 & 5.7 & 1.48 & $0.58 ; 3.80$ \\
\hline $41-44$ & 7 & 1.5 & 2 & 2.0 & 1.34 & $0.27 ; 6.55$ \\
\hline \multicolumn{7}{|l|}{ Level of education } \\
\hline University & 111 & 23.3 & 22 & 21.2 & 1.00 & Reference \\
\hline Senior high school & 288 & 60.5 & 57 & 54.8 & 0.99 & $0.58 ; 1.71$ \\
\hline None-junior high school & 77 & 16.2 & 25 & 24.0 & 1.64 & $0.86 ; 3.11$ \\
\hline \multicolumn{7}{|l|}{ Occupation } \\
\hline Housewife & 300 & 63.1 & 69 & 66.4 & 1.00 & Reference \\
\hline Employed & 176 & 36.9 & 35 & 33.6 & 0.86 & $0.55 ; 1.35$ \\
\hline \multicolumn{7}{|l|}{ Number of pregnancies } \\
\hline $2-15$ & 249 & 52.3 & 58 & 55.8 & 1.00 & Reference \\
\hline First & 227 & 47.7 & 46 & 44.2 & 0.87 & $0.57 ; 1.33$ \\
\hline \multicolumn{7}{|l|}{ Number of children } \\
\hline $1-9$ & 224 & 47.1 & 50 & 48.1 & 1.00 & Reference \\
\hline None & 252 & 52.9 & 54 & 51.9 & 0.96 & $0.63 ; 1.47$ \\
\hline \multicolumn{7}{|l|}{ Number of deliveries } \\
\hline $1-10$ & 241 & 50.6 & 53 & 50.9 & 1.00 & Reference \\
\hline None & 235 & 49.4 & 51 & 49.1 & 0.97 & $0.65 ; 1.51$ \\
\hline \multicolumn{7}{|l|}{ Physical health } \\
\hline Healthy & 440 & 92.4 & 95 & 91.4 & 1.00 & Reference \\
\hline Not healthy & 36 & 7.6 & 9 & 8.6 & 1.16 & $0.54 ; 2.48$ \\
\hline
\end{tabular}


The final model (Table 3) showed the relationship between several risk factors and APD. This model indicated that low monthly expenditure increased the risk of APD when compared to those with high monthly expenditures. However, those with middle monthly expenditure were not found to have an increased risk of APD.
Compare to subjects without stress before pregnancy, those with stress before pregnancy had twice-the chance of APD. Furthermore, the presence of stress during pregnancy also increased the risk two-fold. Problems with the husband's mental status almost increased the risk two-fold.

Table 2. Some histories of wife and risk of antepartum depression (APD)

\begin{tabular}{|c|c|c|c|c|c|c|}
\hline & \multicolumn{2}{|c|}{$\begin{array}{c}\text { Non-APD } \\
(\mathrm{N}=476)\end{array}$} & \multicolumn{2}{|c|}{$\begin{array}{c}\text { APD } \\
(N=104)\end{array}$} & \multirow{2}{*}{$\begin{array}{l}\text { Crude odds } \\
\quad \text { ratio }\end{array}$} & \multirow{2}{*}{$\begin{array}{c}95 \% \\
\text { confidence intervals }\end{array}$} \\
\hline & $\mathrm{n}$ & $\%$ & $\mathrm{n}$ & $\%$ & & \\
\hline \multicolumn{7}{|c|}{ Marital adjustment of wife } \\
\hline Present & 252 & 52.9 & 39 & 37.5 & 1.00 & Reference \\
\hline Not present & 224 & 47.1 & 65 & 62.5 & 1.88 & $1.21 ; 2.89$ \\
\hline \multicolumn{7}{|c|}{ History of depressive episode } \\
\hline Not present & 434 & 91.2 & 83 & 79.8 & 1.00 & Reference \\
\hline Present & 42 & 8.8 & 21 & 20.1 & 2.61 & $1.47 ; 4.64$ \\
\hline \multicolumn{7}{|c|}{ History of premenstrual syndrome } \\
\hline Not present & 351 & 73.7 & 67 & 64.4 & 1.00 & Reference \\
\hline Present & 125 & 26.3 & 37 & 35.6 & 1.55 & $0.99 ; 2.43$ \\
\hline
\end{tabular}

Table 3. Relationship between several mental status, socio-econmic and risk of antepartum depression (APD)

\begin{tabular}{|c|c|c|c|c|c|c|}
\hline & \multicolumn{2}{|c|}{$\begin{array}{c}\text { Non-APD } \\
(\mathrm{N}=476)\end{array}$} & \multicolumn{2}{|c|}{$\begin{array}{c}\text { APD } \\
(\mathrm{N}=104)\end{array}$} & \multirow{2}{*}{$\begin{array}{l}\text { Adjusted } \\
\text { odds ratio }\end{array}$} & \multirow{2}{*}{$\begin{array}{c}95 \% \\
\text { confidence intervals }\end{array}$} \\
\hline & $\mathrm{n}$ & $\%$ & $\mathrm{n}$ & $\%$ & & \\
\hline \multicolumn{7}{|c|}{ Stress before pregnancy } \\
\hline Not present & 424 & 89.1 & 70 & 67.3 & 1.00 & Reference \\
\hline Present & 52 & 10.9 & 34 & 32.7 & 2.04 & $1.12 ; 3.74$ \\
\hline \multicolumn{7}{|c|}{ Stress during pregnancy } \\
\hline Not present & 382 & 80.3 & 57 & 54.8 & 1.00 & Reference \\
\hline Present & 94 & 19.7 & 47 & 45.2 & 2.13 & $1.24 ; 3.74$ \\
\hline \multicolumn{7}{|c|}{ Marital adjustment of husband } \\
\hline Present & 274 & 57.6 & 33 & 31.7 & 1.00 & Reference \\
\hline Not present & 202 & 42.4 & 71 & 68.3 & 2.27 & $1.41 ; 3.70$ \\
\hline \multicolumn{7}{|l|}{ Social support } \\
\hline Present & 227 & 47.7 & 26 & 25,0 & 1.00 & Reference \\
\hline Not present & 249 & 52.3 & 78 & 75,0 & 2.07 & $1.24 ; 3.44$ \\
\hline \multicolumn{7}{|c|}{ Mental health status of husband } \\
\hline No problem & 323 & 67.9 & 48 & 46.1 & 1.00 & Reference \\
\hline Problem & 153 & 32.1 & 56 & 53.9 & 1.86 & $1.17 ; 2.97$ \\
\hline \multicolumn{7}{|c|}{ Monthly expenditure (in Rupiahs) } \\
\hline $150,000-950,000$ & 68 & 14.3 & 9 & 8.7 & 1.00 & Reference \\
\hline $80,000-149,999$ & 155 & 32.6 & 33 & 31.7 & 1.91 & $0.83 ; 4.40$ \\
\hline $19,000-79,999$ & 253 & 53.1 & 62 & 59.6 & 2.27 & $1.03 ; 5.01$ \\
\hline
\end{tabular}

Adjusted each other for variables listed on this tables and level of education. 


\section{DISCUSSION}

There are limitations must be considered in the interpretation of our findings, since the subjects included were confirmed during 35 to 42 weeks of pregnancy and screening was only undertaken once.

The proportion of APD in this study was $18 \%$ among pregnant women. It was lower when compared to other studies. For example, other studies have reported approximately 47\% women in the low socioeconomic status and $20 \%$ women of the higher socioeconomic status, were indicated as depressive. ${ }^{4}$ The difference in results were probably due to the method of data collection. In this study, the women were put into one group in the third trimester, without differentiating between the socioeconomic status and were screened with EPDS. In the other studies, the data collected were from the second trimester and divided into two groups of pregnant women with different socioeconomic status and indicated a depressive state by a score of 10 or more on the Beck Depression Inventory (BDI). ${ }^{4}$

This study proved that several factors played a significant role in the risk of having APD. As with previous studies, several factors were evaluated and proved that the cause of APD was multifactorial. ${ }^{4,11}$

When related to stress before and during pregnancy, it was found in this study that there was a 2.04 and 2.13 chance of having APD, respectively. Psychiatric problems during pregnancy can be distressing for the mother, and can be potentially serious. ${ }^{2}$ The magnitude of the problem is therefore considered sufficiently significant, since however mild the mental disorder, it will have some impact on the woman who will not be able to function optimally. Previous study proved that stress in pregnant women was significantly associated with spontaneous preterm birth and with low birth weight. ${ }^{12}$

This study revealed that strained marital relationship was found to increase the risk of APD by 2.28 times. The result of other studies has also shown that marital conflict was associated with depression in early pregnancy. ${ }^{13}$ Furthermore, having a partner but not living with him was associated with depressive symptoms. ${ }^{4}$ According to these results marital relationship is well correlated to APD. ${ }^{5}$

This study found that pregnant women with inadequate social support have twice the risk of having APD. In a prior study, the unavailability of social support when needed is itself strongly associated with the depressive symptomatology of pregnant women. Thus, social support appears to be more relevant to mental health when a person perceives a need for it. ${ }^{4}$ This is supported by the theory that asserts the importance of social support in the development of emotional disorders during pregnancy. ${ }^{14}$

The relationship between prior mental health status of the husband and postpartum depression have already been reported by previous studies. ${ }^{13,15}$ This study has also shown that poor mental health status of the husband exerted a two-fold increase risk of APD.

A low monthly expenditure indicated a significant risk of having APD by 2.27 times. The result of other research, reported that low socioeconomic status was not significantly associated with depression score. But variables such as "lack of money for basic needs" was associated quite strongly with depression. ${ }^{4}$

Marital risk factor of wife was not included in the final model. This marital risk factor of wife was hiden by the other dominant risk factors such as marital adjustment of husband. The results of previous study ${ }^{13}$ showed that in early pregnancy, marital problems (the presence of chronic tension, causing periods of hostility) in one or both partners co-existed with antenatal depression.

Furthermore, the history of depressive episode was not in the final model. This finding similar with other study ${ }^{4}$ which indicated that some women experienced their first depressive episode during their first pregnancy. In this study, the EPDS score was dominated by depression without history of depressive episode. History of premenstrual syndrome was also exclude from the final model, but in this study still not clear.

It is therefore important to communicate the possibility of depression in pregnant women through family counseling, courses, workshops, and others connected with mental health. In a previous study in Yogyakarta, for example, it was proven that groups entering programs such as family counseling and courses on mental health, yielded significant results compared to the control group that did not attend such program. ${ }^{16}$

In conclusion, the prevalence of APD was found to be $18 \%$ among pregnant women. It was related to stress 
before and during pregnancy, marital relationship, social support, husband's mental status, and monthly expenditure.

\section{Acknowledgements}

The author wishes to thank Prof. Bambang Sutrisna (School of Public Health, University of Indonesia) and Prof. Sasanto Wibisono (Faculty of Medicine, University of Indonesia) for technical assistance in the preparation on this study. Special thanks are extended to the Director, colleagues, and staff of the Persahabatan General Hospital in Jakarta and Cipto Mangunkusumo General Hospital, the Chairman and colleagues of the Department of Psychiatry Cipto Mangunkusumo General Hospital/University of Indonesia Faculty of Medicine, and the study subjects for their invaluable support and cooperation in this study. And lastly to Prof. Bastaman Basuki and dr. Minarma Siagian who reviewed earlier drafts of this manuscript that improved the final product.

\section{REFERENCES}

1. Green JE, Murray D. The use of the Edinburgh postnatal depression scale in research to explore the relationship between antenatal and postnatal dysphoria. In: Cox J, Holden J, editors. Perinatal psychiatry. Use and misuse of the Edinburgh postnatal depression scale. London: Gaskell; 1996.p.181-98.

2. Appleby L, Fox H, Shaw M, et al. The Psychiatrist in the Obstetric Unit. Establishing a Liaison Service. Br J Psychiat 1989; 154:510-5.

3. Yalom ID, Lunde DT, Moos RH, Hamburg DA. Postpartum blues syndrome. A description and related variable. Arch Gen Psychiat 1968; 18:16-27.

4. Seguin L, Potvin L, Denis MS, Loiselle J. Chronic stressors, social support, and depression during pregnancy. Am Coll Obst Gyn 1995; 85:583-9.
5. Brockington I. Depression. Mental illness during pregnancy. Pregnancy and mental health. Motherhood and mental health. Oxford: Oxford University Press Inc; 1999.

6. Elvira DS, Kusumadewi I, Wibisono S, Ismail RI. Postpartum depression. A multi-ethnic and multi-center cohort study (Center Jakarta). Proceedings of the Japan Society for the Promotion of Science (JSPS)-DGHE Large Scale Cooperative Research (LSCR) Indonesia and Japan Non Communicable Disease (NCD) in Tropical Area. Subject Neuropsychiatric Diseases. Project-Collaborative Research; 22-24 November 2000; Surabaya; 2000. pp. 10-23.

7. Martono H. Determining the normal standard T-Score of the SCL-90 psychometric evaluation instrument, and applying on out-patients of the Psychiatric Clinic of the Cipto Mangunkusumo Hospital Jakarta [thesis]. Jakarta: Univ Indonesia; 1994.

8. Hosmer DW, Lemeshow S. Applied logistic regression. $2^{\text {nd }}$ ed. New York. John Willey \& Sons. 2000.

9. Breslow NE, Day NE. Statistical Methods in Cancer Research Vol I. The analysis of case-control studies (IARC Sci. Publ No.32). Lyon, France: International Agency for Research on Cancer, 1980. p 93-115.

10. Stata Corporation. Stata statistical software: Release 6.0. Texas: College Station; 1999.

11. Evans J, Heron J, Francomb H, Oke S, Golding J. Cohort study of depressed mood during pregnancy and after childbirth. BMJ 2001; 323:257-60

12. Copper RL, Goldenberg RL, Das A, Elder N, Swain M, Norman G, et al. The preterm prediction study: Maternal stress is associated with spontaneous preterm birth at less than thirty-five weeks' gestation. Am J Obst Gyn 1996; 175:1286-92.

13. Kumar R, Robson KM. A prospective study of emotional disorders in childbearing women. $\mathrm{Br} \mathrm{J}$ Psychiat 1984;144:35-47.

14. Stowe ZN, Nemeroff CB. Women at risk for postpartumonset major depression. Am J Obst Gyn 1995; 173:63945 .

15. Lovestone S, Kumar R. Postnatal psychiatric illness: The impact on partners. Br J Psychiat 1993;163:210-6.

16. Muchlas M. Improving family strengths through family closeness in order to raise family well-being). [Inaugural address as professor]. Yogyakarta; 1998. 